\title{
STUDI KANDUNGAN LOGAM BERAT KADMIUM $(C d)$ PADA SPESIES IKAN KEMBUNG (Rastrelliger kanagurta) DAN KERANG DARAH (Anadara granosa) DI PERAIRAN MANYAR, GRESIK DAN DI PERAIRAN JABON, SIDOARJO
}

\author{
THE STUDY OF HEAVY METAL CONTENT CADMIUM (Cd) SPECIES ON (Rastrelliger \\ kanagurata) AND (Anadara granosa) IN MANYAR, GRESIK AND JABON \\ SIDOARJO
}

\author{
Muhammad Nur Faith Zulkarnain, Boedi Setya Rahardja dan Moch. Amin Alamsjah \\ Fakultas Perikanan dan Kelautan Universitas Airlangga \\ Kampus C Mulyorejo - Surabaya, 60115 Telp. 031-5911451
}

\begin{abstract}
Marine pollution to be contamination that often occurs at this time. Commonly, one of pollutants found at sea is heavy metal pollution because heavy metal can be dangerous, it is not degraded by the body, toxicity properties in living organisms even at low concentrations and can be accumulated in a certain period. Heavy metals are found in marine waters are polluted Cadmium $(\mathrm{Cd})$. Biota were used as indicators of environmental pollution marine white is fish and shellfish bloating blood. Standard National Indonesia (SNI) based, maximum Content of Cadmium in the body of organisms was $0,2 \mathrm{mg} / \mathrm{kg}$.

The aimed of the study to determine differences in Heavy Metal Cadmium fish and shellfish bloating blood contained in Manyar, Gresik waters and the Jabon, Sidoarjo waters. This research is descriptive and the data obtained and analyzed Independent Samples T 2 test. Cadmium content analysis done by destructive methods then performed using Atomic Absorbance readings Spectrophotometric (AAS).

Based on analysis of the has been done that cadmium content the heavy metal of cadmium content in the Manyar Gresik water, in Gresik on Mackerel average rate (0.12888) ppm, and still below the Indonesian National Standard threshold (SNI 0,2 mg/kg), and blood clams at (1.24483) ppm have exceeded the Indonesian National Standard (SNI 0,2 $\mathrm{mg} / \mathrm{kg}$ ). The content of cadmium in the Jabon Sidoarjo waters, the mackerel average rate $(0,01891) \mathrm{ppm}$, and still below the threshold Indonesian National Standard (SNI 0,2 $\mathrm{mg} / \mathrm{kg})$, and blood clams at $(0,69937) \mathrm{ppm}$, has exceeded threshold of the Indonesian National Standard (SNI 0,2 $\mathrm{mg} / \mathrm{kg}$ ).
\end{abstract}

Keywords : blood shellfish, fish, heavy metal cadmium $(\mathrm{Cd})$

\section{Pendahuluan}

Perairan Manyar Gresik merupakan muara dari beberapa sungai yang ada di Jawa Timur disebabkan muara perairan Manyar Gresik di lewati aliran air dari sungai yang bermuara ke laut. Limbah buangan pabrik di sepanjang sungai Manyar yang bermuara ke laut menjadi penyebab utama pencemaran (Trilaksani dkk., 1998). Djanat, (2007) menjelaskan bahwa pencemaran di Perairan Manyar Gresik, yang tercemar kandungan kadmium yang tercemar pada air laut sebesar $0,0010 \mathrm{mg} / \mathrm{kg}$. Sedangkan menurut Retno dan Mahmudiono (2009) menjelaskan bahwa kerang yang tercemar kadmium di Perairan Manyar Gresik sebesar $0,02 \mathrm{mg} / \mathrm{kg}$ masih di bawah ambang batasnya yaitu $(0,2 \mathrm{mg} / \mathrm{kg})$ menurut Standar Nasional Indonesia No. 01-2896-2009.

Menurut Setyowati dkk (2010) untuk di Perairan Jabon Sidoarjo. Kandungan kadmium rata-rata pada ikan yang tercemar sebesar $0,03 \mathrm{mg} / \mathrm{kg}$ dan menurut Tuti dan Jovita (2005) kerang yang tercemar kadmium di Perairan Sidoarjo sebesar $0,03 \mathrm{mg} / \mathrm{kg}$ juga masih di ambang batas baik SNI yaitu (0,2 $\mathrm{mg} / \mathrm{kg}$ ). Menurut (Geonarso, 1988 dalam Chahaya, 2003), untuk mengetahui efek toksik dari beberapa polutan kimia dalam suatu lingkungan dapat di uji dengan menggunakan spesies yang terdapat pada lingkungan tersebut, salah satunya adalah ikan dan kerang. Ikan dan kerang sebagai salah satu biota air dapat dijadikan sebagai salah satu indikator pencemaran yang terjadi di dalam perairan. Menurut paparan diatas dari tahun ke tahun diduga pencemaran kadmium meningkat dan oleh karena itu perlu adanya penelitian tentang kandungan logam berat kadmium (Cd) pada ikan kembung dan kerang darah di perairan Manyar Gresik dan di Perairan Jabon Sidoarjo.

Perumusan Masalah yang timbul dari uraian diatas adalah apakah terdapat perbedaan 
kandungan logam berat kadmium pada ikan dan kerang di perairan Manyar Gresik, dan di Perairan Jabon Sidoarjo, dan apakah kandungan logam berat kadmium yang terdapat pada ikan dan kerang di perairan Manyar Gresik, dan di Perairan Jabon Sidoarjo telah melebihi ambang batas yang diperbolehkan sesuai Standar Nasional Indonesia SNI. Tujuan dari penelitian ini adalah untuk mengetahui jumlah kandungan kadmium (Cd) pada ikan kembung dan kerang darah yang ada di perairan Manyar Gresik, dan di Perairan Jabon Sidoarjo, serta untuk mengetahui kadar logam berat kadmium pada ikan kembung dan kerang darah di Perairan Manyar Gresik berada diatas atau dibawah ambang batas kadar kadmium yang diperbolehkan dalam ikan kembung dan kerang darah menurut Standar Nasional Indonesia (SNI).

\section{Metodologi}

Tempat dan Waktu

Penelitian ini dilakukan pada bulan Juni - Juli 2012. lokasi pengambilan sampel dilakukan di dua tempat, yaitu Perairan Manyar Gresik dan di Perairan Jabon Sidoarjo. Masingmasing tempat di tentukan pengambilan sampel sebanyak 3 stasiun, wilayah yaitu bantaran sungai, wilayah mangrove dan muara. Setiap 1 stasiun dilakukan 3 kali ulangan bagi sampel ikan kembung dan kerang darah.

\section{Materi Penelitian}

Bahan-bahan yang akan digunakan dalam penelitian ini adalah organisme laut berupa ikan dan kerang serta sampel air dan sedimen. Sampel yang didapat diperoleh dari nelayan sekitar Perairan Manyar Gresik dan Perairan Jabon Sidoarjo. Bahan yang digunakan untuk analisis kandungan kadmium pada biota, air maupun sedimen yaitu larutan $\mathrm{HCl}$, larutan HNO3 pekat, H2SO4, larutan baku kadmium dan aquades. Peralatan penelitian yang diperlukan untuk pengambilan sampel adalah termometer, refraktometer, kertas $\mathrm{pH}$, plastik pembungkus $5 \mathrm{~kg}$, Coolbox. Peralatan untuk analisis logam berat adalah satu perangkat alat Atomic Absorption Spectrometry (AAS), gelas beker, aluminium foil, homogenizer, botol polypropylene, cawan porselen tertutup, corong plastik, desikator, gelas ukur, hot plate, labu takar, microwave, mikropipet, oven, pipet tetes, pipet volumetrik, pisau, frezeer, sendok plastik, dan neraca analitik.

\footnotetext{
Metode Penelitian

Penelitian ini merupakan penelitian deskriptif yaitu suatu penggambaran keadaan
}

yang bertujuan untuk membuat gambaran atau lukisan secara sistematis, faktual dan akurat mengenai fakta - fakta, sifat serta hubungan antar fenomena yang diselidiki. Metode penelitian yang akan digunakan adalah metode survei yang dilakukan di perairan Manyar, Gresik dan Perairan Jabon Sidoarjo dan hasilnya akan dianalisis di laboratorium. Metode survei adalah penyelidikan yang diadakan untuk memperoleh fakta - fakta dari gejala - gejala yang ada dan mencari keterangan secara faktual (Nazir, 2011).

\section{Cara Pengambilan Sampel}

A. Penentuan Stasiun Pengamatan

Pengambilan sampel dilakukan pada tiga stasiun yang ditentukan sebelumnya. Penentuan koordinat geografis setiap stasiun pengambilan sampel menggunakan Global Positioning System (GPS). Koordinat yang ditentukan dapat digunakan sebagai acuan dalam pengambilan sampel untuk memperoleh data yang diinginkan (Hadi, 2007). Lokasi Jarak pengambilan sampel dari bibir pantai berkisar sekitar $1 \mathrm{~km}$.

\section{B. Pengambilan Sampel}

Pengambilan sampel berupa ikan, kerang dan air laut dilakukan secara langsung di perairan Manyar Gresik dan perairan Jabon Sidoarjo. Ikan yang di ambil memiliki ukuran panjang $15 \mathrm{~cm}-30 \mathrm{~cm}$ sedangkan Kerang yang di ambil memiliki ukuran panjang yaitu $3 \mathrm{~cm}-$ $5 \mathrm{~cm}$ dan ukuran kerang yang panjang kandungan kadmiumnya lebih besar (Afriansyah, 2009). Sampel yang sudah diambil kemudian disimpan didalam coolbox untuk menghindari adanya kerusakan pada sampel baru dilakukan pengujian kadar kadmium di laboratorium dan selanjutnya dilakukan analisis data.

\section{Metode Pengujian Logam Berat}

Analisis kadar kadmium pada biota dilakukan dengan metode $A A S$. Metode ini dilakukan dengan cara timbang sampel sebanyak 5 gram, kemudian sampel dimasukkan ke dalam labu digestion. Sampel yang telah di timbang kemudian ditambahkan $5 \mathrm{ml} \mathrm{HNO}_{3}, 5$ $\mathrm{ml} \mathrm{H}_{2} \mathrm{SO}_{4}, 10 \mathrm{ml}$ aquabides. Sampel yang telah tercampur kemudian di biarkan bereaksi secara sempurna. Larutan sampel kemudian di panaskan pada suhu kurang lebih $60^{\circ} \mathrm{C}$ selama 30 menit. Larutan sampel kemudian dinginkan selama lima menit saerta ditambahkan $10 \mathrm{ml}$ $\mathrm{HNO}_{3}$. Larutan sampel kemudian dipanaskan hingga larutan dalam labu berkurang setangah dari vulomenya. Larutan sampel dibiarkan 
selama lima menit dan ditambahkan $1 \mathrm{ml} \mathrm{H}_{2} \mathrm{O}_{2}$ hingga warna berubah menjadi jernih. Larutan sampel tersebut kemudian pindah dalam labu ukur $100 \mathrm{ml}$. Larutan sampel tersebut kemudian di uji menggunakan $A A S$

Parameter Pengamatan

Parameter yang diukur meliputi: parameter utama dan parameter penunjang. Parameter utama, yaitu pengukuran kadar kadmium yang ada pada ikan kembung, kerang darah. Parameter penunjang, meliputi kualitas air, yaitu suhu, salinitas, $\mathrm{pH}$, kadar kadmium pada air dan sedimen. Analisis parameter utama yaitu kadar kadmium yang terdapat pada beberapa jenis ikan menggunakan $A A S$ type AA 6200, Analisis parameter penunjang menggunakan termometer, salinometer dan kertas $\mathrm{pH}$.

Analisis Data

Analisis data dalam penelitian ini menggunakan Uji T 2 sampel independent (Sugiyono, 2009). Uji ini dilakukan untuk membandingkan kadar kadmium yang ada di dalam tubuh ikan kembung dan kerang darah pada Perairan Manyar, Gresik dan di Perairan Jabon, Sidoarjo.

\section{Hasil dan Pembahasan}

Berdasarkan penelitian yang telah dilakukan di dua tempat yaitu, Perairan Manyar Gresik dan Perairan Jabon Sidoarjo, diperoleh data tentang kandungan logam berat kadmium pada Ikan Kembung (Rastrelliger kanagurta) yang diambil dari kedua perairan tersebut. Hasil analisis kadmium pada Ikan Kembung (Rastrelliger kanagurta) dapat dilihat pada Tabel 1.

Berdasarkan penelitian yang telah dilakukan di dua tempat yaitu, Perairan Manyar Gresik dan Perairan Jabon Sidoarjo, diperoleh data tentang kandungan logam berat kadmium pada kerang darah yang diambil dari kedua perairan tersebut. Hasil analisi kadmium pada kerang darah dapat dilihat pada Tabel 2.

Berdasarkan penelitian yang telah dilakukan di dua tempat yaitu, Perairan Manyar Gresik dan Perairan Jabon Sidoarjo, diperoleh data tentang kandungan logam berat kadmium air dan sedimen yang diambil dari kedua perairan tersebut. Hasil analisis kadmium pada air dan sedimen dapat dilihat pada Tabel 3 dan Tabel 4.

Pada perhitungan staistika untuk air dan sedimen diperoleh hasil tidak terdapat perbedaan yang nyata dimana $\mathrm{p}<0,05$. Hal ini berarti bahwa tidak terdapat perbedaan kandungan logam berat Kadmium pada air dan sedimen di perairan Manyar Gresik dan perairan Jabon Sidoarjo. Kandungan logam berat kadmium pada air dan sedimen di Perairan Manyar Gresik dan Perairan Jabon Sidoarjo telah melebihi ambang batas SNI.

Tabel 1. Data Analisis Kandungan Kadmium pada Ikan Kembung (mg/kg)

\begin{tabular}{|l|l|l|l|l|l|l|}
\hline \multirow{2}{*}{ Stasiun } & \multicolumn{3}{|c|}{ Perairan Manyar Gresik } & \multicolumn{3}{c|}{ Perairan Jabon Sidoarjo } \\
\cline { 2 - 7 } & Ulangan 1 & Ulangan 2 & Ulangan 3 & Ulangan 1 & Ulangan 2 & Ulangan 3 \\
\hline ST 1 & 0,009 & 0,009 & 0,009 & 0,0625 & 0,009 & 0,009 \\
ST 2 & 0,009 & 0,009 & 0,0338 & 0,009 & 0,009 & 0,009 \\
ST 3 & 0,9981 & 0,0785 & 0,009 & 0,0249 & 0,0288 & 0,009 \\
\hline
\end{tabular}

Tabel 2. Data Analisis Kandungan Kadmium pada Kerang Darah (mg/kg)

\begin{tabular}{|l|l|l|l|l|l|l|}
\hline \multirow{2}{*}{ Stasiun } & \multicolumn{3}{|c|}{ Perairan Manyar Gresik } & \multicolumn{3}{c|}{ Perairan Jabon Sidoarjo } \\
\cline { 2 - 7 } & Ulangan 1 & Ulangan 2 & Ulangan 3 & Ulangan1 & Ulangan 2 & Ulangan 3 \\
\hline ST 1 & 0,8007 & 0,7174 & 2.1128 & 0,7016 & 0,6101 & 0,6285 \\
ST 2 & 0,6143 & 1.9185 & 1.3035 & 0,9071 & 0,5338 & 1.2643 \\
ST 3 & 1.1474 & 1.2368 & 1.3489 & 0,5697 & 0,5266 & 0,5527 \\
\hline
\end{tabular}

Tabel 3. Data Analisis Kandungan Kadmium pada Air Laut (mg/kg)

\begin{tabular}{|c|c|c|}
\hline Stasiun & $\begin{array}{c}\text { Perairan Manyar } \\
\text { Gresik }\end{array}$ & $\begin{array}{c}\text { Perairan Jabon } \\
\text { Sidoarjo }\end{array}$ \\
\hline ST 1 & 0,001 & 0,001 \\
ST 2 & 0,001 & 0,001 \\
ST 3 & 0,001 & 0,001 \\
\hline
\end{tabular}


Tabel 4. Data Analisis Kandungan Kadmium pada Sedimen (mg/kg)

\begin{tabular}{|c|c|c|}
\hline \multirow{2}{*}{ Stasiun } & $\begin{array}{c}\text { Perairan Manyar } \\
\text { Gresik }\end{array}$ & $\begin{array}{c}\text { Perairan Jabon } \\
\text { Sidoarjo }\end{array}$ \\
\hline ST 1 & 0,7205 & 0,0563 \\
ST 2 & 0,6329 & 0,6788 \\
ST 3 & 0,8214 & 0,1118 \\
\hline
\end{tabular}

Tabel 5. Data Hasil Pengukuran Kualitas Air

\begin{tabular}{|c|c|c|c|c|c|c|}
\hline \multirow{3}{*}{ Stasiun } & \multicolumn{6}{|c|}{ Parameter yang diukur } \\
\cline { 2 - 7 } & \multicolumn{3}{|c|}{ Perairan Manyar Gresik } & \multicolumn{2}{c|}{ Perairan Jabon Sidoarjo } \\
\cline { 2 - 7 } & Suhu & Ph & Salinitas & Suhu & pH & Salinitas \\
\hline ST1 & 31 & 8 & 28 & 30 & 8 & 26 \\
ST2 & 31 & 8 & 28 & 29 & 8 & 26 \\
ST3 & 30 & 8 & 28 & 29 & 8 & 26 \\
\hline
\end{tabular}

Berdasarkan hasil penelitian diperoleh data mengenai kualitas air laut stasiun pengambilan sampel di perairan Manyar Gresik dan perairan Jabon Sidoarjo. Data hasil pengukuran kualitas air laut dapat dilihat pada (Tabel 5).

Menurut Nontji (1987), suhu air permukaan di perairan Indonesia berkisar antara $28-31^{\circ} \mathrm{C}$ dan dalam setahun terdapat dua suhu maksimum yaitu pada musim pancaroba awal tahun (April - Mei) dan pancaroba akhir tahun (November). Dari penelitian yang telah dilakukan, diketahui bahwa suhu di Perairan Manyar Gresik berkisar antara $30-31{ }^{\circ} \mathrm{C}$. Hasil yang sama ditunjukkan oleh hasil pengukuran suhu di Perairan Jabon Sidoarjo yaitu 29 - 30 ${ }^{0} \mathrm{C}$. Pengukuran $\mathrm{pH}$ di Perairan Manyar Gresik dan Perairan Jabon Sidoarjo juga menunjukkan hasil yang sama, yaitu 8 .

Sebagaimana diketahui pencemaran lingkungan yang disebabkan oleh adanya bahan pencemar yang mengandung logam berat, membahayakan bagi hidup dan kehidupan, baik secara langsung (ekosistem perairan) maupun tidak langsung (manusia). Keberadaan logam berat di lingkungan perairan sangat perlu diuji keberadaannya baik di badan perairan tersebut maupun bagi organisme yang mendiaminya. Untuk itu maka pengujian kandungan logam berat pada penelitian ini dilakukan terhadap air, sedimen dan ikan dan kerang sebagai organisme uji. Logam berat yang diamati adalah kadmium (Cd). Kadmium (Cd) yang masuk ke dalam badan perairan sebagai dampak dari aktivitas kehidupan manusia ada bermacam bentuk. Diantaranya adalah air buangan (limbah) dari industri yang berkaitan dengan Kadmium (Cd), air buangan dari pertambangan bijih timah hitam dan sisa industri baterai. Buanganbuangan tersebut akan jatuh pada jalur-jalur perairan seperti muara sungai untuk kemudian akan dibawa terus menuju lautan. Logam berat kadmium (Cd) dan bermacam-macam bentuk persenyawaannya dapat masuk ke lingkungan, terutama sekali merupakan efek samping dari aktivitas yang dilakukan manusia. Logam kadmium (Cd) juga akan mengalami proses biotransformasi dan bioakumalasi dalam organisme hidup. Logam ini masuk ke dalam tubuh bersama makanan yang dikonsumsi, tetapi makanan tersebut telah terkontaminasi oleh logam Cd dan atau persenyawaannya.

Kandungan kadmium pada ikan perairan yang tercemar mengakibatkan organism-organisme yang hidup di perairan tersebut, termasuk ikan juga dapat terkontaminasi. Logam berat merupakan bahan pencemar yang dapat berkumpul dalam tubuh mahkluk hidup. Proses bioakumulasi logam berat didalam tubuh ikan dapat melalui 2 cara yaitu secara langsung dan tidak langsung kontaminasi secara langsung terjadi apabila ikan terkena langsung dari air sedangkan kontaminasi tidak langsung akan dialami bila logam berat masuk melalui makanan (Suci et al., 1982 dalam BTKL 1999), kandungan logam berat juga terdapat dalam tubuh manusia terutama dalam darah dan air susu ibu, hal ini diduga akibat dari konsumsi makanan yang terkontaminasi logam berat.

Berdasarkan data analisis kandungan kadmium pada ikan kembung (Tabel 1) di Perairan Manyar Gresik dan Perairan Jabon Sidoarjo, menunjukkan adanya akumulasi logam berat kadmium. Rata - rata kandungan kadmium pada Ikan Kembung di Perairan Manyar Gresik menunjukkan nilai pada stasiun 1 adalah 0,009 ppm, pada stasiun 2 adalah $0,01726 \mathrm{ppm}$, dan pada stasiun 3 diperoleh hasil 0,36186 ppm, sehingga dari ketiga stasiun di Perairan Manyar Gresik diperoleh hasil rata-rata kandungan kadmium sebesar 0,12888 ppm. 
Data rata-rata kandungan kadmium pada ketiga stasiun pengambilan sampel menunjukkan kandungan kadmium pada ikan kembung di Perairan Manyar Gresik masih di bawah ambang batas SNI sebesar $0,2 \mathrm{mg} / \mathrm{kg}$.

Akumulasi kadmium kadmium tertinggi ditemukan pada kerang darah, baik yang berada di Perairan Manyar Gresik dan Perairan Jabon Sidoarjo, dengan metode destruksi menunjukkan adanya akumulasi logam beat kadmium. Rata - rata kandungan kadmium pada ikan kembung di Perairan Manyar Gresik menunjukkan nilai pada stasiun 1 adalah 1.21033 ppm, pada stasiun 2 adalah 1.27876 ppm, pada stasiun 3 adalah 1.24436 ppm, sehingga dari ketiga stasiun di Perairan Manyar Gresik diperoleh hasil rata-rata kandungan kadmium sebesar 1.24483 ppm. Hal ini sesuai dengan pendapat Leslie dan lee dalam Fauzi, (2009) yang menyataan bahwa kerang merupakan hewan filter feeder yang mengakumulasi bahan yang tersaring di dalam insangnya. Dalam prosesnya bakteri dan mikroorganisme lain yang ada di sekelilingnya dapat terakumulasi dan mencapai jumlah yang membahayakan untuk dikonsumsi. Berdasarkan sifat makan kerang yang filter feeder sehingga potensi menyerap polutan dari lingkungan sekitar akan semakin tinggi. Pada jaringan insang kerang, terjadi regulasi metabolisme parsial sehingga mengakumulasi zinc.

\section{Kesimpulan}

Berdasarkan hasil penelitian yang telah dilakukan, maka dapat diambil kesimpulan tidak terdapat perbedaan nyata antara kandungan kadmium pada ikan kembung di Manyar Gresik dan Jabon Sidoarjo dengan kandungan Standard Nasional Indonesia, terdapat perbedaan sangat nyata kandungan kadmium pada kerang darah di perairan Manyar Gresik dan Jabon Sidoarjo dengan kandungan Standard Nasional Indonesia dan terdapat perbedaan yang nyata antara kandungan kadmium pada ikan kembung dan kerang darah di perairan Manyar Gresik dan Jabon Sidoarjo.

Berdasarkan hasil penelitan yang telah dilkaukan, maka perlu dikemukakan beberapa saran, yaitu pemerintah sebaiknya melakukan pengawasan terhadap pembuangan limbah industri maupun limbah rumah tangga ke perairan laut, mengingat banyak limbah industri yang dibuang ke perairan laut yang menyebabkan akumulasi logam berat dan pencemar lain pada biota semakin tinggi dan perlu adanya pengolahan limbah buangan industri sebelum akhirnya dialirkan ke laut, untuk mengurangi konsentrasi logam berat maupun bahan pencemar lain yang masuk kedalam perairan laut, serta masyarakat harus lebih selektif dalam memilih dan mengkonsumsi biota laut terutama kerang darah, karena sifat kerang darah tersebut dapat mengakumulasi logam berat di lingkungan perairan laut.

\section{Daftar Pustaka}

Afriansyah, A. 2009. Konsentrasi Kadmium (Cd) dan Tembaga $(\mathrm{Cu})$ dalam Air, Seston, Kerang dan Fraksinasinya dalam Sedimen di Perairan Delta Berau, Kalimantan Timur. Skripsi. Program Studi ilmu dan Teknologi Kelautan Fakultas Perikanan dan Ilmu Kelautan IPB. Bogor. 10 hal.

Balai Teknik Kesehatan Lingkungan (BTKL). 1999. Pengkajian sumber pencemar logam berat wilayah kali Surabaya. Kehilir atau pantai Kenjeran Surabaya.

Cahaya I. 2003. Ikan, sebagai Alat Monitor Pencemaran. http://library.usu.ac.id/ download/fkm/fkm- indra\%20c2.pdf. di akses tanggal 13 Agustus 2012.

Fauzi, I. 2009. Bahan Baku Perikanan. http://iptek-akdinbemfaperi.blogspot. com/ 2009/06/bahan-baku-perikananbbi.html. Diakses tanggal 3 Mei 2012.

Hadi, A. 2007. Prinsip Pengelolaan Pengambilan Sampel Lingkungan. Gramedia Pustaka Utama. Jakarta. 131 hal.

Nazir, M. 2011. Metode Penelitian. Ghalia Indonesia. Bogor. Hal 55 - 56.

Nontji, A.1984. Biomassadan produktivitas. Fitoplankton diperairan teluk Jakarta serta kaitannya dengan faktor-faktor lingkungan. Suatu Thesis Fakultas Pasca Sarjana IPB. Bogor. 241 hal.

Retno, A dan T. Mahmudiono. 2009. Kadar Logam Berat Cadmium, Protein dan Organoleptik padadaging Bivalvia dan Perendaman Larutan Asam Cuka. Fakultas Kesehatan Masyarakat, Universitas Airlangga. 10 hal.

Setyowati, A., D. Hidayati, Awik P.D.N., N. Abdulgani. 2010. Studi Histopatologi Hatilkan Belanak (Mugil cephalus) Di Muara Sungai Aloo Sidoarjo. 1 hal.

Sugiyono. 2009. Statistika untuk Penelitian. Alfabeta. Bandung.

Trilaksani, W., R. Rudy, Nitibaskara, dan A. Khudori. 1998. Kandungan Logam Berat Merkuri (Hg) dan Kadmium (Cd) Pada Kupang Merah (Musculita Senhausia). Buletin Teknologi hasil 
Studi Kandungan Logam Berat......

Perikanan Vol. V (1): 25-2. ISSN 0854-9230.

Tuti, H. S. dan T.M. Jovita. 2005. Kandungan Logam Berat Pada beberapa Lokasi Perairan Indonesia Pada tahun 20012005. 9 hal. 